\title{
EOZINOFILIJOS SĄSAJOS SU ŠIRDIES IR KRAUJAGYSLIŲ LIGOMIS
}

\author{
Arnoldas Leleika ${ }^{1}$, Einius Trumpa ${ }^{1}$, Palmira Leišyte $\dot{e}^{2,3}$ \\ ${ }^{1}$ Lietuvos sveikatos moksly universiteto Medicinos akademijos Medicinos fakultetas, \\ ${ }^{2}$ Lietuvos sveikatos mokslu universiteto Medicinos akademijos \\ Medicinos fakulteto Vidaus ligu klinika, \\ ${ }^{3}$ Lietuvos sveikatos moksly universiteto Kauno ligonine
}

Raktažodžiai: eozinofilija, širdies pažeidimas, vaskulopatija, išeminè širdies liga, arterinè hipertenzija.

\begin{abstract}
Santrauka
Medicinoje eozinofiliniai granulocitai daugiausiai žinomi kaip kraujo ląstelès, kurios dalyvauja alerginių reakcijų, helmintozių bei bronchinès astmos gynybos mechanizmuose. Šių ląstelių bei širdies ir kraujagyslių ligų sąsaja Lietuvoje ir pasaulyje dar mažai nagrinèta. Dažniausiai atlikti tyrimai su nedidelëmis žmonių populiacijomis, nes tokių ívykių pasitaiko retai, nors gydytojams, tiriantiems ligoni, ne visada pavyksta nustatyti ligos priežastị. Tyrimo tikslas - išsiaiškinti eozinofilinių granulocitų kiekio padidejjimo koreliaciją su širdies bei kraujagyslių ligų išsivystymu; pristatyti jau atliktus klinikinius tyrimus, aptariant ligų klinikines formas, epidemiologiją, riziką sirgti; atskleisti būtinybę analizuoti eozinofilinių granulocitų padidejjimą bendrame kraujo vaizde.

Sisteminė literatūros apžvalga atlikta PubMed, UpToDate elektroninèse medicininių publikacijų paieškos sistemose. Atrenkant tinkamas publikacijas, buvo naudojami raktažodžiai ir jų deriniai: eosinophilia, heart damage, ischemia, arterial hypertension, coronary heart disease. Analizei atrinktos daugiausia pirminès publikacijos bei klinikiniai tyrimai. Atlikus tyrimą, pastebèta, jog eozinofilinių granulocitų padidejjimas koreliuoja ne vien su alergijomis, atopija, bronchine astma, helmintozèmis, bet ir su širdies bei kraujagyslių ligomis. Nustatyta, kad šios efektorinès ląstelès infiltruoja ịvairius audinius, sukelia uždegimą, organų disfunkciją. Ištirta, jog eozinofilija reikšmingai susijusi su vainikinèmis arterijomis, kai kuriems pacientams sukelia sunkią išeminę širdies ligą, kuri dažnai baigiasi mirtimi. Pastebėta, jog eozinofilija reikšmingai siejasi su arterijų kalcifikacija, todèl paspartejja arterinès hipertenzijos progresavimas.
\end{abstract}

\section{Ivadas}

Medicinoje eozinofiliniai granulocitai daugiausia žinomi kaip kraujo ląstelès, kurios dalyvauja alerginių reakcijų, helmintozių bei bronchinès astmos gynybos mechanizmuose. Lietuvoje ir pasaulyje dar mažai nagrinèta sąsaja tarp šių ląstelių bei širdies ir kraujagyslių ligų. Dažniausiai atlikti tyrimai su nedidelemis žmonių populiacijomis, nes tokie ívykiai pasitaiko retai, tad gydytojams, tiriantiems ligoni, ne visada pavyksta nustatyti ligos priežastį.

Tyrimo tikslas - išsiaiškinti eozinofilinių granulocitu kiekio padidejjimo koreliaciją su širdies bei kraujagyslių ligų išsivystymu; pristatyti jau atliktus klinikinius tyrimus, aptariant ligų klinikines formas, epidemiologiją, riziką sirgti; atskleisti būtinybę analizuoti eozinofilinių granulocitų padidèjimą bendrame kraujo vaizde.

\section{Tyrimo medžiaga ir metodai}

Sisteminè literatūros apžvalga atlikta PubMed, UpToDate elektroninėse medicininių publikacijų paieškos sistemose. Atrenkant tinkamas publikacijas, buvo naudojami raktažodžiai ir jų deriniai: eosinophilia, heart damage, ischemia, arterial hypertension, coronary heart disease. Analizei atrinktos daugiausia pirminès publikacijos bei klinikiniai tyrimai.

\section{Rezultatai}

Sveiko žmogaus periferinio kraujo norma yra laikomas eozinofilų kiekis vienetais, kuris svyruoja tarp 0,35$0,5 \times 10^{9} / 1$. Kiekis, didesnis už $0,5 \times 10^{9} / 1$, laikomas padidejjusiu ir vadinamas eozinofilija. Šios būklès stiprumas skirstomas ì lengvą (absoliutus eozinofilų skaičius $-0,5-1,5 \times 10^{9} / 1$ ), vidutinį (eozinofilų kiekis yra $\left.1,5-5 \times 10^{9} / 1\right)$ ir sunkų (eozinofilų kiekis yra $\left.>5 \times 10^{9} / 1\right)$ [1]. Christian L. Andersen ir kitu 2015 metais atliktame tyrime teigiama, kad eozinofilija yra santykinai dažnas reiškinys rutiniškai atliekamuose bendrojo kraujo tyrimuose, nes iš kohortos, kurią sudare 359950 individų, eozinofilija, kurios metu eozinofilų skaičius buvo 
didesnis už $0,5 \times 10^{9} / 1$, pasireiškè 4 proc. pacientų, o tai yra 14406 individai [2].

Eozinofilija širdies pažeidimo kontekste. Eozinofilinė širdies liga yra santykinai reta būklè, kurią pirmasis pastebèjo ir aprašė Wilhelm Löffler 1936 metais. Jis šią patologiją pavadino fibroplastiniu pasieniniu endomiokarditu su kraujyje stebima eozinofilija, geriau žinomą Löffler'io endokardito vardu [3]. Širdies ligos, nesusijusios su ateroskleroze, reumatu ar arterine hipertenzija, nustatomos 20 proc. žmonių. Vienas iš prototipinių pavyzdžiu yra progresuojantis širdies nepakankamumas, kurị sukelia padidejusi eozinofilų koncentracija kraujyje [4]. Širdies pažeidimas dèl eozinofilijos gali būti skirstomas ị tris chronologines stadijas: infiltraciją, trombozę ir fibrozę [3]. Tai susiję su šių ląstelių infiltracija ị širdies audinius bei citotoksinių mediatorių išskyrimu, kurie ir sukelia pažaidą. Endokardo bei miokardo pažeidimas taip pat gali būti susijęs su trombų susiformavimu, o tai lemia padidejjusią embolizacijos riziką. Ilgai užsitęsusi eozinofilija gali turèti įtakos vystytis restrikcinei kardiomiopatijai dèl endokardo pakeitimo fibroziniu jungiamuoju audiniu. Dèl endokardo fibrozavimo bei trombozès gali vystytis vožtuvų nepakankamumas [4].

Vaskulopatijos. 1989 metais buvo atrasta eozinofilinių granulocitų lokalizacija vainikinių kraujagyslių adventicijoje bei aplink ją esančiame jungiamajame audinyje. Tokia būklè su klinikine išraiška pavadinta eozinofiliniu vainikinių kraujagyslių periarteritu. 2012 metais H. Kajihara su kolegomis atliko septynias autopsijas, norèdami susieti šios ligos morfologines bei klinikines išraiškas. Pirmasis klinikinis požymis, pasireiškęs visiems tiriamiesiems - tipinis krūtinès anginos skausmas, kuris tęsèsi kelias savaites ar mènesius, o paros laikotarpiu dažniausiai pasireikšdavo tarp vèlaus vakaro bei ankstyvo ryto. Mirtis ištikdavo dažniausiai šiuo paros laikotarpiu, dažniau ankstyvą rytą. Šių ligonių istorijoje nebuvo bronchinès astmos ar alergijų. Morfologinio tyrimo metu stebeta epikardinių arterijų infiltracija eozinofiliniais granulocitais, kurie destési adventicijoje bei aplink esanti jungiamaji audini, o kraujagysliu intima ir medija buvo neinfiltruotos. Šiems ligoniams dažniausiai būdavo nustatoma Prinzmetal'io tipo vazospazminè krūtinés angina [5]. 2005 metais K. Taira ir kt. aprašè atvejị, kai pasireiškus Prinzmetal'io variantinès anginos simptomams, žmogus mirè dẻl skilvelių virpèjimo.
Anamnezèje nurodyta, jog tiriamasis praeityje nebuvo sirgęs bronchine astma ar alergijomis. Autopsijos metu dešiniojoje vainikinejje arterijoje, ištyrus mikroskopini preparatą, nustatyta eozinofilija, kuri apèmè adventicijos sluoksnį. Pažymèta, jog kituose organuose nebuvo aptikta vaskulito požymių. Išvadose, kaip galutinė diagnozė, buvo nurodytas izoliuotas eozinofilinis koronarinis periarteritas [6]. T. Nakazawa ir kt. (2010), Y. Fengping ir kt. (2011) aprašè panašius atvejus, atitinkamai 70 metų vyro bei 54 metų moters kaip izoliuotą eozinofilinį koronarinįvainikinių kraujagyslių periarteritą, kurie morfologiniu ištyrimu bei klinikiais požymiais siejasi su anksčiau minètais [7,8]. Analizuojant labai svarbu atskirti eozinofilinį vainikinių kraujagyslių periarteritą nuo daugiamazginio poliarterito bei alerginio granulomatozinio angito (Churg-Strauss sindromo). Daugiamazginis poliarteritas daugiau žinomas kaip lètinè sisteminè liga, apimanti ne vieną organų sistemą. Labiausiai stebimas kirmèlinèje ataugoje, tulžies pūslèje, žarnose, gimdoje ir sẻklidèse [9-11]. Šių organų arterijos buvo paveiktos nekrozuojančio arterito su gijimo stadijomis. Keliuose klinikinuose atvejuose nustatyta ir polimazginio arterito pasireiškimas vainikinejje kraujotakoje. Pagrindinis skirtumas nuo eozinofilinio poliarterito buvo lokalizacija ne vien epikardinèse kraujagyslèse, bet ir smulkiose intrakardinèse [12-15]. Trys aiškūs požymiai leidžia diferencijuoti alergini granulomatozinị angitą nuo aptartų patologijų: 1) bronchinès astmos vyravimas; 2) audinių ar organų eozinofilija; 3) granulomatozinis vaskulitas kartu su eozinofilu infiltracija. Apibendrindami galime pasakyti, jog eozinofilinį vainikinių kraujagyslių periarteritą nuo daugiamazginio poliarterito ar alerginio granulomatozinio angito galima diferencijuoti pagal 1 lentelèje aprašytus diferencinès diagnostikos požymius [5].

Eozinofilija siejama ir su vaskulopatijomis: mazginiu poliarteritu, eozinofiline granulomatoze su poliangitu $[16,17]$. Hipereozinofilijos sindromas gali turèti įtakos smulkių ir vidutinio dydžio arterijų pažeidimui, kuri pasireiškia distaline išemija, pasibaigiančia galūnès amputacija, jei kraujotaka neatkuriama. Atliktoje prancūzų bei amerikiečių studijoje nustatyta, kad dar iki arterijų pažaidos, kuri dažniausiai (92\% atvejų) lokalizuojasi viršutinèse galūnèse, nustatomas padidèjęs eozinofilinių granulocitų kiekis kraujyje [18]. Nors tai reta hipereozinofilinio sindromo išraiška, ją paste-

1 lentelè. Alerginio granulomatozinio angito diagnostikos požymiai.

\begin{tabular}{|c|c|}
\hline Klinikiniai požymiai & Morfopatologiniai požymiai \\
\hline $\begin{array}{l}\text { 1. Angininis skausmas pasireiškia tarp vakaro } \\
\text { bei ankstyvo ryto (Prinzmetal'io } \\
\text { vazospazminè angina) } \\
\text { 2. Alerginès anamnezės nebuvimas } \\
\text { 3. Sunkiai nuspejjama mirtis, dažniau ištinkanti } \\
\text { anksti ryte }\end{array}$ & $\begin{array}{l}\text { 1. Eozinoflinių granulocitų infiltracija epikardinių } \\
\text { vainikinkių arterijų adventicijoje bei jos } \\
\text { jungiamajame audinyje } \\
\text { 2. Fibrininès nekrozè ar mazginių pokyčių gali ir } \\
\text { nebūti paveiktose kraujgyslèse } \\
\text { 3. Kituose organuose nèra vaskulitinių požymių }\end{array}$ \\
\hline
\end{tabular}


bejjus galima išsaugoti paciento galūnę nuo amputacijos.

Su eozinofilija susijusiai kraujagyslių patologijai priskiriamas ir Churg-Strauss sindromas, kuomet stebima miokardo išemija, nesant vainikinių kraujagyslių obstrukcijos požymių. Tai autoimuninis vaskulitas, labiau būdingas ligoniams su anksčiau aptikta atopija, vèlyvos pradžios bronchine astma [19].

Išeminių būklių pasireiškimas eozinofilijos fone. $\mathrm{Nu}$ statyta, jog miokardo išemija gali koreliuoti kartu su eozinofilija. Dar 1950 metais dèl alerginès reakcijos penicilinui buvo nustatytas ryšys tarp alergijos bei miokardo išemijos. Šiuo metu ši būklè vadinama Kounis sindromu ir apibrèžiama kaip ūmus koronarinis sindromas, kuris pasireiškia nestabilia vazospazmine arba nevazospazmine krūtinès angina, arba ūmiu miokardo infarktu alergijos ar padidejusio jautrumo fone. Dažniausiai pasireiškia 40-70 metų žmonèms ir sudaro 68 proc. atvejų [20]. Nustatomi trys šio sindromo tipai. Pirmasis, kai alergine reakcija sukelia vainikinių arterijų spazmą ir ümią išemiją su ar be troponino I pakilimo. Antrasis tipas remiasi aterosklerotinės plokštelès atitrūkimu, kurị sukelia alerginè reakcija ir vainikinès arterijos spindžio mažejimas, galintis tapti ūmaus miokardo infarkto priežastimi. Trečiasis tipas siejamas su stentų tromboze ir eozinofilija [21]. Amerikiečių 2007-2014 metais atliktame tyrime buvo ịtraukti dèl alerginès reakcijos hospitalizuoti 235240 asmenys, iš kurių $2616(1,1 \%)$ atitiko Kounis sindromo kriterijus. Nustatyta, kad Kounis sindromas pasireiškia vyresniems pacientams, kurių amžiaus vidurkis yra 65,9 \pm 14 metų, dažnesnis vyrams. Remiantis šiuo tyrimu, padaryta išvada, jog mirties rizika didesné tiems, kuriems alerginé reakcija sukèlè Kounis sindromą [22].

Eozinofiliniai granulocitai dalyvauja trombozès, vazokonstrikcijos, uždegimo bei endotelio disfunkcijos patogenezejje, išskirdami tam tikrus mediatorius [23,24]. Jie stimuliuoja ir aktyvina trombocitu agregaciją, bet kartu slopina trombozès susidarymą, inhibuodami trombomeduliną [25-27]. Turkijos kardiologų atliktas tyrimas parode ryši tarp eozinofilų skaičiaus padidejimo bei sumažèjusios vaikinikinių arterijos kraujotakos greičio. Tyrimas atliktas 2011-2013 metais, retrospektyviai analizuojant atliktas vainikiniu arterijų angiografijas dèl išeminių pokyčių, ịvertinant kraujotakos greitị. I tyrimą buvo ịtraukiamai pacientai, neturintys reikšmingų stenozių vainikinejje kraujotakoje. Iš 6832 tuo laiku atliktų koronografijų, į tyrimą buvo atrinkti 102 pacientai (52 \pm 11 metų, 34 moterys ir 68 vyrai), kuriems pasireiškè sulètejusi koronarinè kraujotaka bei 77 pacientai, kuriems šio požymio nebuvo ir jie laikyti kontroline grupe. Tarp lyginamųjų grupių statistiškai reikšmingo skirtumo nenustatyta lyginant amžių, lytị, kūno masès indeksą, kraujospūdị, Niujorko širdies asociacijos širdies nepakankamumo klases, gliukozès, trigliceridų, leukocitų, trombocitų ir neutrofilų kiekį. Hemoglobino bei eozinofilų kiekio padidèjimas rastas pacientams, kurių sulètejjusi koronarinè kraujotaka, lyginant pacientus su normalia koronarine kraujotaka. Eozinofilu skaičius beveik nesiskyrè tarp pacientų, kuriems pasireiškẻ vienos, dviejų ar trijų vainikinių arterijų suletejjusi kraujotaka [28]. Šio tyrimo išvados parode, jog išemijos ar jos vystymosi metu gali būti padidèjęs eozinofilinių granulocitų kiekis, kuris gali lemti tolesnę ligos ar būklès eigą.

Eozinofilinių granulocitų įtaka aterosklerozès patogenezei. M. Tanaka ir kt. (2012) aprašè Japonijoje, Kyoto ligoninès kardiologijos skyriuje 2006-2009 atliktą tyrimą, kuriame nustatè ryšį tarp eozinofilų skaičiaus padidèjimo bei aterosklerozès. Pagrindinis tikslas buvo ịvertinti vainikinių arterijų kalcifikaciją su eozinofilijos pasireiškimu. Tyrime dalyvavo 1363 asmenys, iš kurių 772 vyrai ir 591 moteris, kuriems įtariama vainikinių kraujagyslių liga. Ieškota koreliacijų tarp eozinofilų skaičiaus bei pagrindinių širdies ir kraujagyslių ligų rizikos veiksnių, įskaitant amžių, kūno masės indeksą, rūkymą, hipertenziją, dislipidemiją, cukrinị diabetą, $\mathrm{C}$ reaktyvuji baltymą, glomerulofiltracijos greiti. Išvadose pateikta, jog lytis, rūkymas ir reikšmingos stenozès koreliavo su eozinofilų kiekio padidejjimu. Ištirta, jog tarp vainikinių arterijų kalcifikacijos bei KMI, CRB, bendro leukocitų skaičiaus ir amžiaus koreliacijų nebuvo. Reikšmingos vainikinių arterijų kalcifikacijos metu nustatytas eozinofilų skaičius svyravo nuo $0,155 \times 10^{9} / 1$ iki $0,346 \times 10^{9} / 1$ [29]. Ankstesni epidemiologiniai bei klinikiniai tyrimai parodè, jog eozinofilų padidejjimą galima sieti su vainikinių arterijų ligomis [30-32].

\section{Rezultatų aptarimas}

Šios literatūros apžvalgos tikslas buvo išsiaiškinti eozinofilijos koreliaciją su širdies bei kraujagyslių ligomis, pristatyti atliktus klinikinius tyrimus, aptariant ligų klinikines formas, epidemiologiją, riziką sirgti bei parodyti, jog eozinofiliją svarbu atpažinti ir tikslingai nustatyti jos priežasti bei galimas būkles.

Eozinofiliniu granulocitų koncentracijos padidejimas gali būti susijęs su restrikcinio širdies nepakankamumo išsivystymu, kai šios ląstelès infiltuoja endokardą, vẻliau ir miokardą, sukeldamos uždegimą bei kardiomiocitų žūtị.

Išsiaiškinta, jog eozinofiliniai granulocitai gali infiltruotis ir ị kraujagyslių sluoksnius, sukelti sisteminị ar vietinį uždegimą, o vèliau - reikšmingą organo pažeidimą ir disfunkciją. Svarbūs tokie susirgimai kaip eozinofilinis vainikinių kraujagyslių periarteritas, sukeliantis tipinę vazospazminę krūtinès anginą, daugiamazgis poliarteritas, kai eozinofilinių granulocitų infiltracija apima daugelio organų kraujagysles, alerginis granulomatozinis angitas (Churg-Strauss 
sindromas), kai autoimuninis vaskulitas vystosi atopijos, bronchinès astmos fone, sukeldamas vaikinių kraujagyslių obstrukciją ir miokardo išemiją.

Pastebèta, jog eozinofiliniai granulocitai prisideda prie alerginių ir nealerginių išeminių būklių sukèlimo. Sergant Kounis sindromu, padideja mirtingumas dèl miokardo infarkto, lyginant su populiacija, neturinčia šio sindromo. Lèteja vainikinių arterijų kraujotaka dèl padidejusio trombogeniškumo sukeliamos vazokonstrikcijos.

Eozinofilija siejama su arterinių kraujagyslių kalcifikacija, todèl daroma prielaida, jog tai yra susiję ir su arterinès hipertenzijos atsiradimu.

\section{Išvados}

1. Eozinofilinių granulocitų kiekio padidejjimas koreliuoja ne vien su alergijomis, atopija, bronchine astma, helmintozèmis, bet ir su širdies bei kraujagyslių ligomis.

2. Pastebèta, jog šios ląstelès infiltruoja ịvairius audinius, sukelia uždegimą, organų disfunkciją.

3. Ištirta, jog eozinofilija reikšmingai susijusi su vainikinèmis arterijomis, kai kuriems pacientams sukelia sunkią išeminę širdies ligą, kuri dažnai baigiasi mirtimi.

4. Eozinofilija reikšmingai siejasi su arterijų kalcifikacija, tuo paspartindama arterinès hipertenzijos progresavimą.

\section{Literatūra}

1. Gotlib J. World Health Organization-defined eosinophilic disorders: 2017 update on diagnosis, risk stratification, and management. Am J Hematol 2017;92(11):1243-59.

https://doi.org/10.1002/ajh.24880

2. Butt NM, Lambert J, Ali S, Beer PA, Cross NCP, Duncombe A, et al. Guideline for the investigation and management of eosinophilia. Br J Haematol 2017;176(4):553-72.

https://doi.org/10.1111/bjh.14488

3. Séguéla PE, Iriart X, Acar P, Montaudon M, Roudaut R, Thambo JB. Eosinophilic cardiac disease: molecular, clinical and imaging aspects. Arch Cardiovasc Dis 2015;108(4):258-68. https://doi.org/10.1016/j.acvd.2015.01.006

4. Shomali W, Gotlib J. World Health Organization-defined eosinophilic disorders: 2019 update on diagnosis, risk stratification, and management. Am J Hematol 2019;94(10):1149-67. https://doi.org/10.1002/ajh.25617

5. Kajihara H, Tachiyama Y, Hirose T, Takata A, Saito K, Murai $\mathrm{T}$, et al. Eosinophilic coronary periarteritis (vasospastic angina and sudden death), a new type of coronary arteritis: report of seven autopsy cases and a review of the literature. Virchows Arch 2013;462(2):239-48.

https://doi.org/10.1007/s00428-012-1351-7

6. Taira K, Tsunoda R, Watanabe T, Fujino A, Ogyu A, Ashikawa K. An autopsy case of isolated eosinophilic coronary periarteritis: a limited form of Churg-Strauss syndrome or a new entity?
Intern Med 2005;44(6):586-9.

https://doi.org/10.2169/internalmedicine.44.586

7. Nakazawa T, Kondo T, Niu D, Ma D, Mochizuki K, Kawasaki $\mathrm{T}$, et al. Giant oesophageal liposarcoma mimicking spindle cell liposarcoma and containing eosinophilic cells with rhabdomyoblastic differentiation. J Clin Pathol 2010;63(5):469. https://doi.org/10.1136/jcp.2010.075523

8. Fengping Y, Jue H, Qingchun Y, Fangxing H. A case of sudden death due to spontaneous coronary artery dissection. Am J Forensic Med Pathol 2011;32(4):312-3. https://doi.org/10.1097/PAF.0b013e318219c8d3

9. Lhote F, Cohen P, Guillevin L. Polyarteritis nodosa, microscopic polyangiitis and Churg-Strauss syndrome. Lupus 1998;7(4):238-58. https://doi.org/10.1191/096120398678920055

10. Matsumoto T, Kobayashi S, Ogishima D, Aoki Y, Sonoue H, Abe $\mathrm{H}$, et al. Isolated necrotizing arteritis (localized polyarteritis nodosa): examination of the histological process and disease entity based on the histological classification of stage and histological differences from polyarteritis nodosa. Cardiovasc Pathol Off J Soc Cardiovasc Pathol 2007;16(2):92-7. https://doi.org/10.1016/j.carpath.2006.09.005

11. Gambino G, Rizzuto MR, Spallitta IS, Rizzo A, Branca M, Guccione $\mathrm{M}$, et al. Isolated polyarteritis nodosa of the large bowel: a case report. Chir Ital 2008;60(3):469-73.

12. Pick RA, Glover MU, Vieweg WV. Myocardial infarction in a young woman with isolated coronary arteritis. Chest 1982;82(3):378-80.

https://doi.org/10.1378/chest.82.3.378

13. Cassling RS, Lortz JB, Olson DR, Hubbard TF, McManus BM. Fatal vasculitis (periarteritis nodosa) of the coronary arteries: angiographic ambiguities and absence of aneurysms at autopsy. J Am Coll Cardiol. 1985;6(3):707-14.

https://doi.org/10.1016/S0735-1097(85)80135-2

14. Paul RA, Helle MJ, Tarssanen LT. Sudden death as sole symptom of coronary arteritis. Ann Med 1990;22(3):161-2. https://doi.org/10.3109/07853899009147262

15. Dettmeyer R, Amberg R, Varchmin-Schultheiss K, Madea B. Sudden cardiac death due to atypical isolated coronary arteritis? Forensic Sci Int 1998;95(3):193-200. https://doi.org/10.1016/S0379-0738(98)00097-8

16. Kahn JE, Blétry O, Guillevin L. Hypereosinophilic syndromes. Best Pract Res Clin Rheumatol 2008;22(5):863-82. https://doi.org/10.1016/j.berh.2008.09.010

17. Chaigne B, Dion J, Guillevin L, Mouthon L, Terrier B. Physiopathologie de la granulomatose éosinophilique avec polyangéite (Churg-Strauss). Rev Med Interne. 2016;37(5):337-42. https://doi.org/10.1016/j.revmed.2015.10.339

18. Rohmer J, Groh M, Samson M, London J, Jachiet M, Rouzaud $\mathrm{D}$, et al. Distal ischemia as the initial presentation of hypereosinophilic syndrome-related arterial involvement: a case study and literature review. Autoimmun Rev 2019;18(8):828-30. 
https://doi.org/10.1016/j.autrev.2019.06.004

19. Gue YX, Prasad S, Isenberg D, Gorog DA. A case of repetitivemyocardial infarction with unobstructed coronaries due to Churg-Strauss syndrome. Eur Hear J - Case Reports 2019;3(2):1-5. https://doi.org/10.1093/ehjcr/ytz041

20. Abdelghany M, Subedi R, Shah S, Kozman H. Kounis syndrome: A review article on epidemiology, diagnostic findings, management and complications of allergic acute coronary syndrome. Int J Cardiol 2017;232:1-4.

https://doi.org/10.1016/j.ijcard.2017.01.124

21. Gunawardena MDVM, Weerasinghe A, Herath J, Amarasena N. Myocardial infarction associated with eosinophilia and plasma extravasation at multiple sites. A variant of Kounis syndrome A104. BMJ Case Rep 2015;2015.

https://doi.org/10.1136/bcr-2014-207987

22. Desai R, Parekh T, Patel U, Fong HK, Samani S, Patel C, et al. Epidemiology of acute coronary syndrome co-existent with allergic/hypersensitivity/anaphylactic reactions (Kounis syndrome) in the United States: a nationwide inpatient analysis. Int J Cardiol. 2019;292:35-8.

https://doi.org/10.1016/j.ijcard.2019.06.002

23. Sasano H, Virmani R, Patterson RH, Robinowitz M, Guccion JG. Eosinophilic products lead to myocardial damage. Hum Pathol 1989;20(9):850-7.

https://doi.org/10.1016/0046-8177(89)90096-8

24. Wang J-G, Mahmud SA, Thompson JA, Geng J-G, Key NS, Slungaard A. The principal eosinophil peroxidase product, HOSCN, is a uniquely potent phagocyte oxidant inducer of endothelial cell tissue factor activity: a potential mechanism for thrombosis in eosinophilic inflammatory states. Blood 2006;107(2):558-65.

https://doi.org/10.1182/blood-2005-05-2152

25. Rohrbach MS, Wheatley CL, Slifman NR, Gleich GJ. Activation of platelets by eosinophil granule proteins. J Exp Med 1990;172(4):1271-4.

https://doi.org/10.1084/jem.172.4.1271

26. Olsen EG, Spry CJ. Relation between eosinophilia and endomyocardial disease. Prog Cardiovasc Dis 1985;27(4):241-54. https://doi.org/10.1016/0033-0620(85)90008-8

27. Blétry O, Solal P, Herreman G, Brousse N, Chomette G, Bernard JF, et al. [Cardiac manifestations of the hypereosinophilia syndrome: a report on fifteen cases (author's transl)]. Ann Med Interne (Paris) 1981;132(1):16-25.

28. Altas Y, Kurtoglu E, Yaylak B, Baysal E, Ucaman B, Ugurlu $\mathrm{HM}$, et al. The relationship between eosinophilia and slow coronary flow. Ther Clin Risk Manag 2015;11:1187-91. https://doi.org/10.2147/TCRM.S87761

29. Tanaka M, Fukui M, Tomiyasu KI, Akabame S, Nakano K, Yamasaki M, et al. Eosinophil count is positively correlated with coronary artery calcification. Hypertens Res 2012;35(3):325-8. https://doi.org/10.1038/hr.2011.191
30. Prentice RL, Szatrowski TEDP, Fujikura T, Kato H, Mason MW, Hamilton HH. Leukocyte counts and coronary heart disease in a japanese cohort. Am J Epidemiol 1982;116(3):496-509. https://doi.org/10.1093/oxfordjournals.aje.a113434

31. Sweetnam PM, Thomas HF, Yarnell JWG, Baker IA, Elwood PC. Total and differential leukocyte counts as predictors of ischemic heart disease: the caerphilly and speedwell studies. Am J Epidemiol 1997;145(5):416-21.

https://doi.org/10.1093/oxfordjournals.aje.a009123

32. Madjid M, Awan I, Willerson JT, Casscells SW. Leukocyte count and coronary heart disease: implications for risk assessment. J Am Coll Cardiol 2004;44(10):1945-56.

https://doi.org/10.1016/j.jacc.2004.07.056

\section{THE SIGNIFICANCE OF EOSINOPHILIA IN THE EVENT OF CARDIOVASCULAR DISEASES}

\section{A. Leleika, E. Trumpa, P. Leišytè}

Keywords: eosinophilia, heart damage, ischemia, arterial hypertension, coronary heart disease.

Summary

From medical perspective eosinophilic granulocytes are known as blood cells, that participate in allergic reactions, bronchial asthma and defensive mechanisms against helminthiasis. The relationship between these granulocytes and cardiovascular diseases has not been studied much neither in Lithuania or in the world. Most researches have been performed with small study populations, because we have to acknowledge that eosinophilic conditions with cardiovascular complications are rare and medical doctors tend to ignore possible findings during the evaluation of the laboratory test results. Nevertheless, when we can't find the most common etiology of the diseases, we should start looking for less commonly met causes. The aim of the study was: to determine the correlation between the increase in the number of eosinophilic granulocytes and the development of cardiovascular diseases; to demonstrate clinical trials that are already performed, discussing clinical forms, epidemiology and the risk of these cardiovascular pathologies; to reveal the necessity of analyzing the increase of the eosinophilic granulocytes in the blood testing. Systemic review of literature was performed using the following electronic medical publications search systems: PubMed, UpToDate. Keywords and their combinations were used to select suitable publications: eosinophilia, heart damage, ischemia, arterial hypertension, coronary heart disease. Primary publications and clinical trials were selected for the analysis. It was found in the study that the increase in eosinophilic granulocytes correlates not only with allergies, atopy, bronchial asthma, helminthiasis but also with cardiovascular disease. It has also been found that these immune cells infiltrate various tissues, causing inflammation and infiltrated organ dysfunction. Also eosinophilia has been shown to be significantly associated with the pathology of the coronary arteries, causing severe ischemic heart disease in some patients, that often ends fatally. It was also observed that eosinophilia is significantly associated with arterial calcification, thus accelerating the progression of arterial hypertension.

Correspondence to: arnoldas.leleika@gmail.com

Gauta 2021-03-23 